\title{
Effect of fortifying amaranth diets with amino acids, casein and ethylene diamine tetra acetate on broiler performance, amino acid availability and mineral utilisation
}

\author{
L.W. Kabuage ${ }^{1 \#}$, P.N. Mbugua ${ }^{1}$, B.N. Mitaru ${ }^{1}$, T.A. Ngatia $^{2}$ and K. Schafer ${ }^{3}$ \\ ${ }^{1}$ Department of Animal Production, ${ }^{2}$ Department of Veterinary Pathology, Microbiology and Parasitology, \\ University of Nairobi, P.O. Box 29053, Nairobi, Kenya. \\ ${ }^{3}$ Institut fur Tierernahrung, Freie Universitat, Brummer Str. 34, 14195 Berlin, Germany.
}

\begin{abstract}
Two feeding trials with broilers (1-31 days of age) were carried out to determine the effect of fortifying grain amaranth based diets with lysine, methionine, casein and ethylene diamine tetra acetate (EDTA) on broiler performance, amino acid availability, plasma amino acid concentrations and nitrogen and mineral retention. In Trial 1, lysine, lysine plus methionine and casein were separately included in six diets containing either $400 \mathrm{~g} / \mathrm{kg}$ raw or $600 \mathrm{~g} / \mathrm{kg}$ extruded amaranth. Additionally, one $400 \mathrm{~g} / \mathrm{kg}$ raw and one 600 $\mathrm{g} / \mathrm{kg}$ extruded amaranth diets were not fortified. The eight diets were compared to a maize-soyabean meal diet as the control. Chicks on the $600 \mathrm{~g} / \mathrm{kg}$ extruded amaranth diet with casein gave similar body weights at 31 days of age to those on the control diet. Feed intake and nitrogen retention were similar in the control and the extruded amaranth diets. The availability of amino acids was the highest in the chicks on the control diet. The lack of response to lysine, or lysine and methionine inclusions indicated that these amino acids were not limiting to growth in amaranth diets. In Trial 2, three diets contained $400 \mathrm{~g} / \mathrm{kg}$ raw amaranth, and another three, $400 \mathrm{~g} / \mathrm{kg}$ extruded amaranth. Two diets in each group were fortified with either disodium EDTA or casein, while the third was unfortified. Casein inclusion resulted in higher body weights at 31 days of age, but did not affect the plasma concentration of essential amino acids. Dietary EDTA did not enhance mineral retention in the body or the concentration of minerals in plasma. It was evident from both trials that the fortification of amaranth diets with casein improved chick performance and the availability of some amino acids.
\end{abstract}

Keywords: Amaranth, Amaranthus hypochondriacus, broilers, casein, EDTA, amino acids

${ }^{\#}$ Corresponding author. E-mail address: lkabuage@yahoo.co.uk

\section{Introduction}

The provision of high quality poultry feed depends on the availability of raw materials that can appropriately fulfill specified nutrient requirements. The inadequacy of locally produced energy and protein sources in developing countries is a major constraint in their feed manufacturing industry. Although cereal grains as energy source are produced, they are the staple food of the human population in these regions. Many of the protein feedstuffs are imported and thus expensive. Efforts have increased in recent years to identify alternative locally produced and affordable feedstuffs. One such crop is grain amaranth, a fast growing, drought tolerant, herbaceous plant which produces a highly nutritious grain. The crop was first grown as a food grain in central America and has been introduced in Kenya in 1984, where it is occasionally mixed with commonly consumed foods, particularly cereal based flours (Teutonico \& Knorr, 1985; Gupta \& Thimba, 1992; Kauffman, 1992). The suitability of the grain for production in the semi-arid areas of the country and its lack of popularity as a human food renders it potentially ideal for use as a poultry feedstuff. The major species used for grain production are Amaranthus cruentus, A. hypochondriacus and A. caudatus. Grain yields of $2580 \mathrm{~kg} / \mathrm{ha}$ have been reported in research trials in Kenya, which compare favourably with those of other grain crops (Gupta \& Thimba, 1992).

Due to its high concentration of energy, minerals and protein, and its good amino acid composition, grain amaranth has the potential to substitute or complement conventional cereal grain in poultry feeds. Raw A. hypochondriacus grain can effectively replace maize in broiler starter diets at a rate of $200 \mathrm{~g} / \mathrm{kg}$, and this can be increased to $400 \mathrm{~g} / \mathrm{kg}$ if the grain is extruded and steam pelleted (Kabuage, 1996). The poor performance of monogastric animals fed grain amaranth diets has been attributed to anti-nutritional factors in the raw grain (Cheeke \& Bronson, 1980; Pond et al., 1991; Kabuage, 1996). Apparently, the raw grain does not biologically exhibit the protein quality suggested by its amino acid composition (Bressani, 1988). It has been suggested that the anti-nutritional factors might hamper the digestibility of the amaranth protein, thus 
impeding availability of its essential amino acids. Reduced availability of essential amino acids at the digestive stage would further be expected to adversely affect the concentration of amino acids in plasma. According to Hewitt \& Lewis (1972a; b) plasma amino acid concentrations are a sensitive index of changes in the amino acid balance of the diet. Although grain amaranth is richer in minerals than cereal grains, the presence of high phytate concentrations could interfere with their availability (Pedersen et al., 1987). Natural and synthetic chelating agents can markedly improve mineral availability. The high stability constant for ethylene diamine tetra acetate (EDTA) in chelating metal ions enhances the availability of zinc and other divalent cations to chicks (Scott et al., 1982). Amino acids also enhance mineral availability by serving as organic chelates (Scott et al., 1982). There is need to investigate if the fortification of amaranth diets with essential amino acids, casein or EDTA would enhance the utilisation of protein and minerals by broiler chickens. Thermal processing is reported to partially improve the nutritive value of grain amaranth to poultry (Tillman \& Waldroup, 1986; Kabuage, 1996). This present study was designed to determine the effect of fortifying raw and extruded grain amaranth (A. hypochondriacus) diets with certain essential amino acids, casein and EDTA on broiler performance, mineral utilization and amino acid availability.

\section{Materials and methods}

Grain amaranth used in this study was locally obtained from the Nanyuki based Amaranth and Natural Foods Company. Nanyuki is a semi-arid area located at the equator, around $37{ }^{\circ} \mathrm{E}$. The species and variety used (A. hypochondriacus 1024) corresponded with the variety classification of the Rodale Organic Gardening and Farming Research Centre, USA.

In Trial 1, 288 day-old 'Arbor Acres' broiler chicks were divided into 36 groups of eight chicks each. Each group was weighed, assigned to an electrically heated pen of $1 \mathrm{~m}^{2}$ floor space covered with wood shavings litter and fed on one of nine experimental broiler starter diets (Table 1) up to four weeks of age.

Table 1 Ingredient composition $(\mathrm{g} / \mathrm{kg})$ of broiler starter diets used in Trial 1

\begin{tabular}{|c|c|c|c|c|c|c|c|c|c|}
\hline \multicolumn{2}{|c|}{ Amaranth level and type Control } & \multicolumn{4}{|c|}{400 g/kg Raw } & \multicolumn{4}{|c|}{$600 \mathrm{~g} / \mathrm{kg}$ Extruded } \\
\hline Amino acid/Protein & None & None & Lysine & $\begin{array}{r}\text { Lysine } \\
+ \text { Met }^{1}\end{array}$ & Casein & None & Lysine & $\begin{array}{l}\text { Lysine } \\
+ \text { Met }\end{array}$ & Casein \\
\hline Diet & 1 & 2 & 3 & 4 & 5 & 6 & 7 & 8 & 9 \\
\hline \multicolumn{10}{|l|}{ Ingredients } \\
\hline Maize & 542.5 & 187 & 186 & 185.5 & 172 & 0 & 0 & 0 & 0 \\
\hline Amaranth & 0 & 400 & 400 & 400 & 400 & 600 & 600 & 600 & 600 \\
\hline Soya bean meal & 300 & 300 & 300 & 300 & 300 & 300 & 300 & 300 & 300 \\
\hline Fish meal & 80 & 35 & 35 & 35 & 35 & 21.3 & 22 & 21.5 & 7.5 \\
\hline Limestone & 8 & 15 & 15 & 15 & 15 & 20.0 & 19.5 & 19 & 20 \\
\hline Dicalcium phosphate & 12 & 5.5 & 5.5 & 5.5 & 5.5 & 1.2 & 0 & 0 & 0 \\
\hline Lysine & - & - & 1 & 1 & - & - & 1 & 1 & - \\
\hline Methionine & - & - & - & 0.5 & - & - & - & 0.5 & - \\
\hline Casein & - & - & - & - & 15 & - & - & - & 15 \\
\hline Others $^{2}$ & 57.5 & 57.5 & 57.5 & 57.5 & 57.5 & 57.5 & 57.5 & 57.5 & 57.5 \\
\hline
\end{tabular}

\footnotetext{
${ }^{1}$ Methionine

${ }^{2}$ All the diets also contained $(\mathrm{g} / \mathrm{kg})$ : corn oil, 30; salt, 2.5; vitamin $/$ mineral premix, 25 . The premix provided the Following per kilogram of diet: vit. A, $1200 \mathrm{IU}$; vit. D, $3000 \mathrm{IU}$; vit. E, $10 \mathrm{IU}$; vit. K, 4 mg; vit. B $12,0.008$ mg; Nicotinic acid, $20 \mathrm{mg}$; pantothenic acid, $10 \mathrm{mg}$; riboflavin, $6 \mathrm{mg}$; folic acid, $2 \mathrm{mg}$; biotin, $0.08 \mathrm{mg}$; choline, $0.30 \mathrm{mg}$; Manganese, $62.5 \mathrm{mg}$; zinc, $62.5 \mathrm{mg}$; iodine, $1.5 \mathrm{mg}$; copper, $6.25 \mathrm{mg}$; selenium, $0.2 \mathrm{mg}$; ethoxyquin, $9 \mathrm{~g}$.
}

Diet 1 was a maize soyabean meal control diet. Diets $2-5$ contained $400 \mathrm{~g} / \mathrm{kg}$ raw amaranth while Diets 6-8 had $600 \mathrm{~g} / \mathrm{kg}$ extruded amaranth. Fortification with essential amino acids and casein was done as follows:- lysine in Diets 3 and 7; lysine and methionine in Diets 4 and 8; casein in Diets 5 and 9. All the diets were formulated to be iso-nitrogenous and iso-energetic and to meet the NRC (1984) standards. The determined composition and amino acid profiles of the diets used in Trial 1 are presented in Table 2. The 
extrusion process was carried out by passing moistened grain amaranth through a cereal puffing machine with a thermo-controller at $150{ }^{\circ} \mathrm{C}$. The dietary treatments were replicated four times each in a completely randomised design. Feed and water were provided ad libitum. The chicks and feed were weighed once weekly on pen basis. Weekly weight gain and feed intake were obtained respectively as the difference between two consecutive measurements.

On the 29th day of age, a digestibility trial was carried out for the next $72 \mathrm{~h}$, with the same dietary treatments and replicates. Four chicks per pen (replicate) were selected at random and placed in metabolism cages designed for total faecal collection. Clean metal trays were placed under the cages to collect the excreta, following the method of Sibbald (1986). At the end of the trial, the trays were removed and cleaned of any foreign materials such as feathers and scales. The total faecal output was dried in an oven at $105^{\circ} \mathrm{C}$, weighed and samples ground for chemical analysis. Measurements of chick body weight and feed intake per pen were recorded at the start and end of the digestibility trial.

Table 2 Determined composition of broiler starter diets (air dry basis) in Trial 1

\begin{tabular}{|c|c|c|c|c|c|c|c|c|c|}
\hline \multirow{2}{*}{$\frac{\text { Amaranth level and type }}{\text { Amino acid/Protein }}$} & \multirow{2}{*}{$\begin{array}{r}\text { Control } \\
\text { None }\end{array}$} & \multicolumn{4}{|c|}{400 g/kg Raw } & \multicolumn{4}{|c|}{600 g/kg Extruded } \\
\hline & & None & Lysine & $\begin{array}{l}\text { Lysine } \\
+ \text { Met }^{1}\end{array}$ & Casein & None & Lysine & $\begin{array}{l}\text { Lysine } \\
+ \text { Met }\end{array}$ & Casein \\
\hline Diet & 1 & 2 & 3 & 4 & 5 & 6 & 7 & 8 & \\
\hline \multicolumn{10}{|l|}{ Nutrients } \\
\hline $\mathrm{TME}^{2}(\mathrm{MJ} / \mathrm{kg})$ & 15.9 & 15.5 & 15.3 & 15.4 & 15.9 & 16.1 & 15.9 & 16.0 & 16.2 \\
\hline Dry matter (g/kg) & 892 & 893 & 894 & 898 & 891 & 901 & 904 & 907 & 904 \\
\hline Crude protein $(\mathrm{g} / \mathrm{kg})$ & 235 & 223 & 221 & 226 & 235 & 225 & 222 & 230 & 234 \\
\hline Ether extract $(\mathrm{g} / \mathrm{kg})$ & 75.5 & 75.6 & 75.9 & 74.1 & 73.5 & 76.8 & 78.9 & 77.1 & 78.5 \\
\hline Crude fibre (g/kg) & 54.8 & 62.1 & 60.7 & 67.9 & 67.7 & 65.4 & 66.7 & 70.6 & 66.9 \\
\hline $\operatorname{Ash}(g / k g)$ & 60.7 & 61.4 & 62.8 & 61.0 & 64.4 & 59.4 & 57.0 & 59.3 & 55.7 \\
\hline Calcium (g/kg) & 8.5 & 9.0 & 9.4 & 9.1 & 9.5 & 9.8 & 9.6 & 10.4 & 10.8 \\
\hline Phosphorus (g/kg) & 7.2 & 7.8 & 8.1 & 7.9 & 7.5 & 8.1 & 7.8 & 8.0 & 8.6 \\
\hline Magnesium (g/kg) & 2.5 & 3.0 & 3.1 & 2.9 & 3.2 & 3.3 & 3.5 & 3.4 & 3.6 \\
\hline Zinc $(\mathrm{mg} / \mathrm{kg})$ & 103 & 112 & 115 & 120 & 118 & 127 & 132 & 128 & 135 \\
\hline \multicolumn{10}{|l|}{ Amino acid (g/kg) } \\
\hline Arginine & 13.0 & 12.5 & 12.4 & 12.6 & 12.9 & 12.8 & 13.0 & 12.9 & 13.7 \\
\hline Cystine & 3.0 & 3.3 & 3.3 & 3.5 & 3.4 & 3.2 & 3.4 & 3.2 & 3.2 \\
\hline Histidine & 4.9 & 4.5 & 4.3 & 4.3 & 4.7 & 4.3 & 4.4 & 4.3 & 4.7 \\
\hline Isoleucine & 6.0 & 6.1 & 5.4 & 5.0 & 6.5 & 5.4 & 6.0 & 5.8 & 7.1 \\
\hline Leucine & 16.5 & 13.2 & 13.0 & 12.9 & 14.1 & 12.4 & 12.6 & 12.4 & 13.6 \\
\hline Lysine & 11.7 & 10.4 & 10.8 & 10.8 & 11.0 & 10.5 & 11.8 & 11.3 & 11.5 \\
\hline Methionine & 4.1 & 3.7 & 3.7 & 4.3 & 4.0 & 3.8 & 3.9 & 4.2 & 4.0 \\
\hline Phenylalanine & 9.7 & 8.2 & 7.8 & 8.0 & 8.7 & 8.1 & 7.8 & 7.6 & 8.2 \\
\hline Threonine & 8.3 & 7.3 & 7.0 & 7.0 & 7.7 & 7.2 & 7.0 & 7.1 & 7.6 \\
\hline Tyrosine & 8.2 & 6.3 & 6.1 & 6.9 & 7.5 & 6.7 & 6.4 & 6.4 & 6.9 \\
\hline Valine & 6.0 & 6.6 & 6.8 & 6.3 & 7.0 & 5.8 & 5.9 & 6.2 & 7.4 \\
\hline
\end{tabular}

${ }^{1}$ Methionine; ${ }^{2}$ True metabolisable energy.

In Trial 2 grain amaranth was incorporated in each of six broiler starter diets at a rate of $400 \mathrm{~g} / \mathrm{kg}$ (Table 3). The analysed amino acid composition of the diets is shown in Table 4. The diets were in three pairs, each pair comprising of a diet with raw amaranth grain and one with extruded grain. The first pair had no fortification, the second pair had casein while the third contained disodium EDTA. All the diets were formulated to be iso-nitrogenous and iso-energetic and to meet the NRC (1984) standards. Each of the six dietary treatments was assigned to four replicates of eight, one-day old chicks each and fed up to 28 day of age. The feeding trial was conducted in a completely randomised design. The management of the chicks was as described for Trial 1. 
On the 29th day of age, a digestibility trial was carried out as described for Trial 1. At the end of the trial, blood was removed from the wing vein of the birds, pooled in $10 \mathrm{ml}$ heparinised test tubes for birds in each cage (replicate) and thereafter centrifuged at 3000 r.p.m. The plasma was separated and preserved by addition of a few granules of sodium azide. Plasma for subsequent amino acid analyses was frozen. One bird per replicate was picked at random, killed by cervical dislocation and sections of its liver and pancreas obtained. The right thigh was removed and its muscle separated from the femur. The soft tissues (liver, pancreas and thigh muscle) collected, were separately cut up and finely minced in a blender. The femur was boiled for three minutes, cleaned of adhering tissue, dried, weighed and ashed in a furnace at $600{ }^{\circ} \mathrm{C}$.

Table 3 Composition of the broiler starter diets (air dry basis) used in Trial 2

\begin{tabular}{|c|c|c|c|c|c|c|}
\hline \multirow{2}{*}{$\begin{array}{r}\text { Amaranth } \\
\text { Fortification }\end{array}$} & \multicolumn{3}{|c|}{400 g/kg Raw } & \multicolumn{3}{|c|}{$400 \mathrm{~g} / \mathrm{kg}$ Extruded } \\
\hline & None & EDTA $^{2}$ & Casein & None & EDTA & Casein \\
\hline Diet & 1 & 2 & 3 & 4 & 5 & 6 \\
\hline \multicolumn{7}{|l|}{ Ingredients ( $\mathrm{g} / \mathbf{k g}$ ) } \\
\hline Maize & 166 & 165 & 181.5 & 163 & 161 & 181.5 \\
\hline Amaranth & 400 & 400 & 400 & 400 & 400 & 400 \\
\hline Soyabean meal & 300 & 300 & 300 & 300 & 300 & 300 \\
\hline Fish meal & 60 & 60 & 5 & 65 & 65 & 5 \\
\hline Limestone & 15 & 14 & 18 & 14 & 14 & 18 \\
\hline Dicalcium Phosphate & 1.5 & 1.5 & 8 & 0.5 & 0.5 & 8 \\
\hline Casein & - & - & 30 & - & - & 30 \\
\hline EDTA & - & 2 & - & - & 2 & - \\
\hline Others $^{1}$ & 57.5 & 57.5 & 57.5 & 57.5 & 57.5 & 57.5 \\
\hline \multicolumn{7}{|l|}{ Nutrients } \\
\hline Dry matter (g/kg) & 894 & 893 & 887 & 899 & 896 & 891 \\
\hline Crude protein $(\mathrm{g} / \mathrm{kg})$ & 211 & 218 & 230 & 216 & 227 & 235 \\
\hline Ether extract $(\mathrm{g} / \mathrm{kg})$ & 72.5 & 77.3 & 79.2 & 66.8 & 67.4 & 71.4 \\
\hline Crude fibre $(\mathrm{g} / \mathrm{kg})$ & 53.3 & 54.2 & 50.8 & 58.6 & 53.9 & 51.7 \\
\hline $\operatorname{Ash}(g / k g)$ & 60.8 & 65.3 & 65.4 & 65.0 & 66.1 & 67.2 \\
\hline $\operatorname{TME}^{3}(\mathrm{MJ} / \mathrm{kg})$ & 15.2 & 15.3 & 15.4 & 15.5 & 15.7 & 15.9 \\
\hline Calcium (g/kg) & 12.4 & 11.8 & 13.1 & 12.9 & 12.2 & 14.4 \\
\hline Phosphorus (g/kg) & 9.2 & 8.0 & 8.7 & 8.6 & 9.1 & 8.6 \\
\hline Magnesium (g/kg) & 2.3 & 2.0 & 2.1 & 2.2 & 2.2 & 2.5 \\
\hline Zinc $(\mathrm{mg} / \mathrm{kg})$ & 103 & 89 & 86 & 79 & 107 & 90 \\
\hline
\end{tabular}

${ }^{1}$ All the diets also contained $(\mathrm{g} / \mathrm{kg})$ : corn oil, 30; salt, 2.5; vitamin $/$ mineral premix, 25 . The premix provided the Following /kg of diet: vit. A, $1200 \mathrm{IU}$; vit. D, $3000 \mathrm{IU}$; vit. E, $10 \mathrm{IU}$; vit. K, 4 mg; vit. B $12,0.008$ mg; Nicotinic acid, $20 \mathrm{mg}$; pantothenic acid, $10 \mathrm{mg}$; riboflavin, $6 \mathrm{mg}$; folic acid, $2 \mathrm{mg}$; biotin, $0.08 \mathrm{mg}$; choline, $0.30 \mathrm{mg}$; Manganese, $62.5 \mathrm{mg}$; zinc, $62.5 \mathrm{mg}$; iodine, $1.5 \mathrm{mg}$; copper, $6.25 \mathrm{mg}$; selenium, $0.2 \mathrm{mg}$; ethoxyquin, $9 \mathrm{~g}$.

${ }^{2}$ Ethylene diamine tetra acetate; ${ }^{3}$ True metabolisable energy.

The diets and excreta samples were subjected to proximate analyses using standard procedures (AOAC, 1984). The mineral concentrations of diets, excreta, ash, soft tissues and plasma were determined by atomic absorption spectrophotometry (AOAC, 1984). Amino acid analyses of diets, excreta and plasma samples were carried out by ion exchange chromatography using an automated amino acid analyser and following the manufacturer's instruction manual and handbook (Pharmacia, 1988a; b). The solid samples were first extracted by acid hydrolysis followed by the amino acid determination using sodium citrate buffers. However, determination of methionine and cystine involved oxidation of samples prior to acid hydrolysis to prevent destruction of these sulphur amino acids. The plasma was deproteinised first, using sulphosalicylic acid before adjusting the $\mathrm{pH}$ to 2.2 with lithium hydroxide and thereafter using lithium citrate 
buffers. The true metabolisable energy concentration of the diets was determined according to the method described by Sibbald (1986). Apparent nutrient retention/availability was calculated as:-

Weight of nutrient ingested - Weight of nutrient in excreta X 100

Weight of nutrient ingested

Data collected in the two trials were subjected to analysis of variance using the general linear model (GLM) procedures (SAS, 1988). Means were compared using the Tukey's multiple range test.

Table 4 Determined amino acid composition $(\mathrm{g} / \mathrm{kg})$ of the diets used in Trial 2 (air dry basis)

\begin{tabular}{lrrrrrr}
\hline \multicolumn{1}{c}{ Amaranth } & \multicolumn{2}{c}{$\mathbf{4 0 0} \mathbf{g} / \mathbf{k g ~ R a w}$} & \multicolumn{2}{c}{$\mathbf{4 0 0} \mathbf{g} / \mathbf{k g}$ Extruded } \\
\hline \multicolumn{1}{c}{ Fortification } & None & EDTA $^{1}$ & Casein & None & EDTA & Casein \\
\hline Diet & 1 & \multicolumn{1}{c}{2} & \multicolumn{1}{c}{3} & \multicolumn{1}{c}{4} & 5 & 6 \\
\hline Amino acids & & & & & & \\
Alanine & 8.9 & 8.9 & 9.7 & 9.4 & 9.4 & 9.7 \\
Arginine & 13.2 & 14.4 & 14.5 & 13.9 & 13.6 & 14.1 \\
Aspartic acid & 20.6 & 19.9 & 21.8 & 21.0 & 20.8 & 22.4 \\
Cystine & 3.5 & 3.5 & 4.0 & 3.6 & 3.6 & 3.8 \\
Glutamic acid & 43.5 & 42.7 & 48.1 & 44.6 & 43.9 & 47.1 \\
Glycine & 10.1 & 10.2 & 10.5 & 10.2 & 10.0 & 10.6 \\
Histidine & 4.8 & 4.9 & 5.3 & 5.0 & 4.8 & 5.1 \\
Isoleucine & 6.5 & 7.6 & 8.4 & 7.4 & 6.5 & 7.9 \\
Leucine & 14.2 & 14.0 & 15.6 & 14.6 & 14.1 & 15.2 \\
Lysine & 11.2 & 11.4 & 12.8 & 12.0 & 11.9 & 12.9 \\
Methionine & 3.7 & 3.8 & 4.0 & 3.5 & 3.4 & 4.3 \\
Phenylalanine & 8.5 & 9.1 & 9.7 & 9.6 & 9.3 & 10.2 \\
Proline & 14.8 & 12.0 & 15.2 & 12.5 & 13.5 & 12.5 \\
Serine & 11.3 & 10.8 & 12.1 & 11.7 & 11.8 & 12.2 \\
Threonine & 7.8 & 7.9 & 8.8 & 8.2 & 7.8 & 8.6 \\
Tyrosine & 6.2 & 7.0 & 7.8 & 7.4 & 7.3 & 8.0 \\
Valine & 8.3 & 8.2 & 9.2 & 8.0 & 7.6 & 8.2 \\
\hline
\end{tabular}

${ }^{\mathrm{T}}$ Ethylene diamine tetra acetate.

\section{Results and discussion}

Results of Trial 1 showed that chicks on raw amaranth diets had lower feed intakes and body weights at 31 days than those on the control and the extruded amaranth diets (Table 5). Chicks on the control diet had the highest $(\mathrm{P}<0.05)$ body weight and feed efficiency. Chicks on extruded amaranth diets gave similar $(\mathrm{P}>0.05)$ nitrogen retentions as those on the control diet. The feed intakes were also similar for these treatments, except for Diet 7. The better chick performance from processed amaranth diets might have been associated with destruction of anti-nutritional factors in the grain, which led to increased feed intake and digestibility (Bressani et al., 1992; Peisker, 1994; Kabuage, 1996)

The availability of essential amino acids was generally high, ranging between 73 and 95\% (Table 5). The highest amino acid availability values were obtained in the control diet. The availability of isoleucine, valine and threonine was higher in all the extruded amaranth diets than in the raw grain diets without casein. Although the feed intakes of the former diets were mostly similar to that of the control diet, they exhibited poorer amino acid availability and lower chick body weights at 31 days of age. The extrusion process might have lowered the protein concentration and digestibility through the 'Maillard reaction', hence reducing amino acid availability (Erbersdobler, 1976; Scott et al., 1982; Wallis \& Ballnave, 1984). Indigestibility accounts for most of the unavailability of amino acids. Heat processed proteins are more resistant to digestive processes than unheated ones, with lysine, glutamic acid, aspartic acid and threonine the most liable to be damaged by heat (Erbersdobler, 1976; Wallis \& Balnave, 1984). This might explain the significant differences in lysine and threonine availability between the control and the extruded amaranth diets in the 
current study. The striking improvement in growth response as a result of fortification with casein (Table 5) implies a deficiency of certain essential amino acids in the unfortified amaranth diets.

Table 5 Broiler performance, nitrogen and mineral retention, and amino acid availability at 31 days of age (Trial 1)

\begin{tabular}{|c|c|c|c|c|c|c|c|c|c|c|}
\hline \multirow{2}{*}{$\frac{\text { Amaranth level and type }}{\text { Amino acid/Protein }}$} & \multirow{2}{*}{$\begin{array}{l}\text { Control } \\
\text { None }\end{array}$} & \multicolumn{4}{|c|}{$400 \mathrm{~g} / \mathrm{kg}$ Raw } & \multicolumn{4}{|c|}{$600 \mathrm{~g} / \mathrm{kg}$ Extruded } & \multirow[b]{3}{*}{ s.e.m. ${ }^{2}$} \\
\hline & & None & $\begin{array}{r}\text { Lysine } \mathrm{L} \\
+\end{array}$ & $\begin{array}{l}\text { ysine } \\
-\mathrm{Met}^{1}\end{array}$ & Casein & None 1 & Lysine 1 & $\begin{array}{l}\text { Lysine } \\
+ \text { Met }\end{array}$ & Casein & \\
\hline Diet & 1 & 2 & 3 & 4 & 5 & 6 & 7 & 8 & 9 & \\
\hline \multicolumn{11}{|l|}{ Response } \\
\hline Body weight (g/bird) & $1090^{\mathrm{a}}$ & $810^{\mathrm{d}}$ & $778^{\mathrm{d}}$ & $800^{\mathrm{d}}$ & $832^{\mathrm{d}}$ & $955^{\mathrm{bc}}$ & $942^{c}$ & $957^{\mathrm{bc}}$ & $1002^{\mathrm{b}}$ & 24.6 \\
\hline Feed intake (g/bird) & $1815^{\mathrm{a}}$ & $1550^{\mathrm{c}}$ & $1473^{\mathrm{d}}$ & $1512^{\mathrm{cd}}$ & $1505^{\mathrm{d}}$ & $1788^{\mathrm{ab}}$ & $1765^{\mathrm{b}}$ & $1785^{\mathrm{ab}}$ & $1809^{\mathrm{a}}$ & 34.5 \\
\hline Feed efficiency (Feed:gain) & $1.75^{\mathrm{c}}$ & $2.04^{\mathrm{a}}$ & $2.02^{\mathrm{ab}}$ & $2.02^{\mathrm{ab}}$ & $1.92^{\mathrm{ab}}$ & $1.98^{\mathrm{ab}}$ & $1.98^{\mathrm{ab}}$ & $1.97^{\mathrm{ab}}$ & $1.90^{\mathrm{b}}$ & 0.02 \\
\hline Nitrogen retention (\%) & $70.7^{\mathrm{a}}$ & $57.8^{\mathrm{c}}$ & $57.3^{\mathrm{c}}$ & $59.9^{\mathrm{bc}}$ & $62.2^{\mathrm{b}}$ & $67.9^{\mathrm{a}}$ & $68.1^{\mathrm{a}}$ & $68.4^{\mathrm{a}}$ & $70.0^{\mathrm{a}}$ & 1.3 \\
\hline Calcium retention (\%) & $42.5^{\mathrm{c}}$ & $36.5^{\mathrm{d}}$ & $34.6^{\mathrm{d}}$ & $35.6^{\mathrm{d}}$ & $34.4^{\mathrm{d}}$ & $45.9^{\mathrm{bc}}$ & $47.5^{\mathrm{bc}}$ & $51.2^{\mathrm{ab}}$ & $53.8^{\mathrm{a}}$ & 1.74 \\
\hline Phosphorus retention (\%) & $50.2^{\mathrm{a}}$ & $43.5^{\mathrm{b}}$ & $46.7^{\mathrm{ab}}$ & $45.1^{\mathrm{ab}}$ & $45.9^{\mathrm{ab}}$ & $50.8^{\mathrm{a}}$ & $50.2^{\mathrm{a}}$ & $49.0^{\mathrm{ab}}$ & $49.0^{\mathrm{ab}}$ & 0.7 \\
\hline Zinc retention (\%) & $0.45^{\mathrm{e}}$ & $-2.71^{\mathrm{g}}$ & $-1.92^{\mathrm{f}}$ & $0.25^{\mathrm{e}}$ & $0.94^{\mathrm{d}}$ & $3.46^{\mathrm{c}}$ & $6.52^{\mathrm{b}}$ & $6.33^{\mathrm{b}}$ & $8.25^{\mathrm{a}}$ & 0.9 \\
\hline \multicolumn{11}{|l|}{ Amino acid availability, \% } \\
\hline Arginine & 95.2 & 93.4 & 94.0 & 93.6 & 94.4 & 93.9 & 93.5 & 92.2 & 94.4 & 0.32 \\
\hline Cystine & $89.6^{\mathrm{a}}$ & $86.7^{\mathrm{ab}}$ & $85.8^{\mathrm{b}}$ & $86.2^{\mathrm{b}}$ & $87.8^{\mathrm{ab}}$ & $85.7^{\mathrm{b}}$ & $86.0^{\mathrm{b}}$ & $86.6^{\mathrm{ab}}$ & $87.6^{\mathrm{ab}}$ & 0.38 \\
\hline Histidine & 93.8 & 90.4 & 89.6 & 88.8 & 90.9 & 89.5 & 90.3 & 88.4 & 89.5 & 0.47 \\
\hline Isoleucine & $88.3^{\mathrm{a}}$ & $83.1^{\mathrm{c}}$ & $79.7^{\mathrm{cd}}$ & $77.8^{\mathrm{d}}$ & $83.5^{\mathrm{b}}$ & $83.7^{\mathrm{b}}$ & $85.1^{\mathrm{ab}}$ & $83.3^{\mathrm{bc}}$ & $88.4^{\mathrm{a}}$ & 0.84 \\
\hline Leucine & $92.7^{\mathrm{a}}$ & $87.5^{\mathrm{b}}$ & $85.6^{\mathrm{b}}$ & $85.3^{\mathrm{b}}$ & $87.9^{\mathrm{b}}$ & $86.5^{\mathrm{b}}$ & $87.3^{\mathrm{b}}$ & $85.1^{\mathrm{b}}$ & $88.1^{\mathrm{b}}$ & 0.6 \\
\hline Lysine & $92.2^{\mathrm{a}}$ & $86.7^{\mathrm{b}}$ & $86.5^{\mathrm{b}}$ & $86.0^{\mathrm{b}}$ & $86.9^{\mathrm{b}}$ & $86.1^{\mathrm{b}}$ & $88.2^{\mathrm{b}}$ & $85.5^{\mathrm{b}}$ & $87.6^{\mathrm{b}}$ & 0.53 \\
\hline Methionine & $94.4^{\mathrm{a}}$ & $90.8^{\mathrm{b}}$ & $90.0^{\mathrm{b}}$ & $90.5^{\mathrm{b}}$ & $90.6^{\mathrm{b}}$ & $91.0^{\mathrm{ab}}$ & $91.1^{\mathrm{ab}}$ & $90.5^{\mathrm{b}}$ & $91.9^{\mathrm{ab}}$ & 0.41 \\
\hline Phenylalanine & $89.6^{\mathrm{a}}$ & $83.5^{\mathrm{ab}}$ & $82.1^{\mathrm{b}}$ & $81.6^{\mathrm{b}}$ & $84.2^{\mathrm{ab}}$ & $83.8^{\mathrm{ab}}$ & $83.6^{\mathrm{ab}}$ & $80.9^{\mathrm{b}}$ & $84.2^{\mathrm{ab}}$ & 0.64 \\
\hline Threonine & $89.2^{\mathrm{a}}$ & $81.8^{\text {bcd }}$ & $81.2^{\mathrm{cd}}$ & $80.6^{\mathrm{d}}$ & $83.9^{\mathrm{bcd}}$ & $83.3^{\text {bcd }}$ & $84.3^{\mathrm{bc}}$ & $83.3^{\mathrm{bcd}}$ & $85.0^{\mathrm{b}}$ & 0.64 \\
\hline Tyrosine & $81.3^{\mathrm{a}}$ & $67.9^{\mathrm{bc}}$ & $64.3^{\mathrm{c}}$ & $66.6^{\mathrm{bc}}$ & $71.7^{\mathrm{b}}$ & $69.8^{\mathrm{bc}}$ & $68.7^{\mathrm{bc}}$ & $68.1^{\mathrm{bc}}$ & $70.4^{\mathrm{b}}$ & 1.13 \\
\hline Valine & $86.8^{\mathrm{a}}$ & $79.4^{\mathrm{bc}}$ & $77.6^{\mathrm{cd}}$ & $73.1^{\mathrm{d}}$ & $82.0^{\mathrm{bc}}$ & $79.9^{\mathrm{bc}}$ & $82.9^{\mathrm{ab}}$ & $81.0^{\mathrm{bc}}$ & $86.7^{\mathrm{a}}$ & 1.04 \\
\hline
\end{tabular}

ab Means with different superscripts within a row are different at $\mathrm{P}<0.05$.

${ }^{1}$ Methionine; ${ }^{2}$ Standard error of mean.

Since the addition of lysine and methionine did not increase body weight, it is evident that these two amino acids were not limiting to growth. Casein apparently provided some essential amino acids which were more limiting than lysine and methionine. Table 2 shows that casein increased the levels of valine, threonine, leucine, isoleucine and arginine in the amaranth diets. In addition, casein increased $(\mathrm{P}<0.05)$ the availability of valine and isoleucine which was notably low in amaranth diets, to equal that of the control (Table 5). However, the dietary levels and availability of leucine and threonine in the amaranth diets were considerably below that of the control diet, even when casein was added (Tables 2 and 5). These two amino acids appeared to be the most limiting in amaranth diets. This is partly in agreement with work by Becker et al. (1981) who reported that leucine followed by valine and threonine were the most limiting amino acids in A. cruentus. The lack of a positive growth response from the inclusion of lysine and methionine also partly agrees with findings reported by Laovoravit et al. (1986) who indicated that lysine in grain amaranth is highly available.

Results of Trial 2 showed that chicks on extruded amaranth diets were heavier $(\mathrm{P}<0.05)$ and had a higher $(\mathrm{P}<0.05)$ feed intake, feed efficiency and nitrogen retention than those on raw amaranth diets (Table 
6). The inclusion of casein in Diets 3 and 6 resulted in higher $(\mathrm{P}<0.05)$ body weights at 31 days compared to the other treatments. Casein generally increased the methionine and isoleucine concentrations of the two diets and this might have enhanced their utilisation. Thermal processing of grain amaranth or fortification of diets with casein did not affect $(\mathrm{P}>0.05)$ plasma amino acid concentrations, except for lysine, which was apparently higher with casein inclusion (Table 7). The plasma amino acid concentrations obtained, were similar to those of growing chicks reported by Hewitt \& Lewis (1972a; b) when tested at a dietary lysine range of $11-12 \mathrm{~g} / \mathrm{kg}$. According to McNab (1980) the concentration of the amino acids in plasma reflects the quantity of the respective amino acids in dietary protein that is available to the bird. Except for methionine and isoleucine, the diets in the current study met the amino acid specifications of growing chicks (NRC, 1984), and this was hence reflected in the normal plasma amino acid concentrations and the high body weights observed.

Table 6 Effect of processing and fortification of amaranth diets on broiler performance at 31 days of age (Trial 2)

\begin{tabular}{|c|c|c|c|c|}
\hline & $\begin{array}{c}\text { Body weight } \\
\text { (g/bird) }\end{array}$ & $\begin{array}{c}\text { Feed intake } \\
(\mathrm{g} / \mathrm{bird})\end{array}$ & $\begin{array}{c}\text { Feed efficiency } \\
\text { (feed:gain) }\end{array}$ & $\begin{array}{c}\text { Nitrogen retention } \\
(\%)\end{array}$ \\
\hline \multicolumn{5}{|c|}{$\begin{array}{lllllllll} & \\
\end{array}$} \\
\hline 1 & $863^{\mathrm{c}}$ & $1528^{\mathrm{b}}$ & 1.88 & $64.0^{\mathrm{c}}$ \\
\hline 2 & $880^{\mathrm{c}}$ & $1566^{\mathrm{b}}$ & 1.89 & $66.2^{\mathrm{bc}}$ \\
\hline 3 & $903^{\mathrm{c}}$ & $1576^{\mathrm{b}}$ & 1.85 & $66.9^{\mathrm{bc}}$ \\
\hline 4 & $983^{\mathrm{b}}$ & $1689^{\mathrm{a}}$ & 1.81 & $72.5^{\mathrm{a}}$ \\
\hline 5 & $993^{\mathrm{b}}$ & $1736^{\mathrm{a}}$ & 1.84 & $70.2^{\mathrm{ab}}$ \\
\hline 6 & $1070^{\mathrm{a}}$ & $1783^{\mathrm{a}}$ & 1.75 & $72.7^{\mathrm{a}}$ \\
\hline s.e.m. ${ }^{1}$ & 22.68 & 29.21 & 0.02 & 1.01 \\
\hline \multicolumn{5}{|l|}{$\begin{array}{l}\text { Main effects } \\
\text { Processing }\end{array}$} \\
\hline Raw & $882^{\mathrm{b}}$ & $1557^{\mathrm{b}}$ & $1.9^{\mathrm{a}}$ & $65.7^{\mathrm{b}}$ \\
\hline Extruded & $1015^{\mathrm{a}}$ & $1736^{\mathrm{a}}$ & $1.8^{\mathrm{b}}$ & $71.8^{\mathrm{a}}$ \\
\hline s.e.m. & 22.7 & 29.2 & 0.02 & 1.01 \\
\hline \multicolumn{5}{|l|}{ Fortification } \\
\hline None & $923^{\mathrm{b}}$ & $1609^{\mathrm{b}}$ & 1.9 & 68.3 \\
\hline $\mathrm{EDTA}^{2}$ & $937^{\mathrm{b}}$ & $1651^{\mathrm{ab}}$ & 1.9 & 68.2 \\
\hline Casein & $987^{\mathrm{a}}$ & $1680^{\mathrm{a}}$ & 1.8 & 69.8 \\
\hline s.e.m. & 22.7 & 29.2 & 0.02 & 1.01 \\
\hline \multicolumn{5}{|l|}{ Interaction } \\
\hline Processing $\mathrm{x}$ Fortification & $\mathrm{ns}^{3}$ & ns & ns & ns \\
\hline
\end{tabular}

The effect of fortifying grain amaranth diets on mineral utilisation was demonstrated in both Trial 1 and 2. In Trial 1, the control and the processed amaranth diets gave the highest mineral retention, especially for calcium and zinc (Table 5). Retention of zinc was generally low for all the diets and negative for some of the raw grain amaranth diets. The second feeding trial similarly showed higher $(\mathrm{P}<0.05)$ retention rates for calcium, phosphorus, magnesium and zinc with the extruded amaranth diets than with those of raw grain (Table 8). This indicated better availability and utilisation of minerals when grain amaranth was extruded. There might have been a positive association between the enhanced protein retention of the extruded amaranth diets and the increased mineral availability, with amino acids acting as organic chelates. Zinc availability in this trial was, however, negative for all the diets. This signified some interference in the 
absorption of this mineral, possibly phytate. High phytate levels could be attributed to the presence of various plant-based ingredients in the diets such as amaranth and soyabean meal. Dietary phytate and fibre are known to regulate zinc turnover by acting as a reserve when the need increases, but offering resistance to free absorption of this mineral when the need is less (Hallmans et al., 1985). In addition, the pancreas plays an important role in zinc homeostasis by providing the major route for endogenous zinc excretion through the pancreatic fluid (Oberleas, 1985). The amaranth diets, especially those of raw grain, might have provoked high losses of zinc through over-secretion of pancreatic enzymes associated with the presence of trypsin inhibitor in the grain. Despite the negative zinc balance, the levels of this mineral in the plasma and body tissues were normal and similar to those obtained by Watkins \& Southern (1993) using maize-soyabean diets containing an adequate $(85 \mathrm{mg} / \mathrm{kg})$ zinc concentration. The mineral concentrations of various bodily tissues and blood plasma in Trial 2 were within the normal ranges (Scott et al., 1982) indicating that the availability of minerals in the grain amaranth diets was adequate for tissue utilisation (Table 8). Inclusion of dietary EDTA did not enhance $(\mathrm{P}>0.05)$ the body retention or the plasma concentration of calcium, magnesium and zinc. It was, therefore, not possible to attribute the higher $(\mathrm{P}<0.05)$ mineral concentrations of some body tissues in the EDTA containing treatments to this mineral chelating supplement.

Table 7 Effect of processing and fortification of amaranth diets on plasma amino acids at 31 days of age (Trial 2)

\begin{tabular}{ccccccr}
\hline & \multicolumn{7}{c}{ Processing } & \multicolumn{3}{c}{ Fortification } \\
& Raw & Extruded & None & EDTA $^{1}$ & Casein & s.e.m. ${ }^{2}$ \\
\hline Plasma amino acid $(\mu \mathbf{m o l e s} / \mathbf{m l})$ & & & & & & \\
Alanine & $0.79^{\mathrm{a}}$ & $0.71^{\mathrm{b}}$ & $0.77^{\mathrm{a}}$ & $0.77^{\mathrm{a}}$ & $0.71^{\mathrm{a}}$ & 0.02 \\
Arginine & 0.47 & 0.45 & 0.48 & 0.47 & 0.44 & 0.01 \\
Aspartic acid & $0.18^{\mathrm{a}}$ & $0.18^{\mathrm{a}}$ & $0.21^{\mathrm{a}}$ & $0.18^{\mathrm{ab}}$ & $0.15^{\mathrm{b}}$ & 0.01 \\
Cystine & 0.06 & 0.05 & 0.06 & 0.05 & 0.05 & 0 \\
Glycine & $0.72^{\mathrm{a}}$ & $0.68^{\mathrm{a}}$ & $0.77^{\mathrm{a}}$ & $0.72^{\mathrm{a}}$ & $0.63^{\mathrm{b}}$ & 0.02 \\
Histidine & 0.17 & 0.14 & 0.15 & 0.15 & 0.18 & 0.01 \\
Isoleucine & 0.16 & 0.17 & 0.17 & 0.16 & 0.17 & 0.01 \\
Leucine & 0.24 & 0.24 & 0.24 & 0.24 & 0.25 & 0.01 \\
Lysine & $0.63^{\mathrm{a}}$ & $0.68^{\mathrm{a}}$ & $0.65^{\mathrm{b}}$ & $0.58^{\mathrm{c}}$ & $0.73^{\mathrm{a}}$ & 0.02 \\
Methionine & $0.06^{\mathrm{a}}$ & $0.07^{\mathrm{a}}$ & $0.07^{\mathrm{a}}$ & $0.07^{\mathrm{a}}$ & $0.07^{\mathrm{a}}$ & 0 \\
Phenylalanine & 0.15 & 0.12 & 0.15 & 0.13 & 0.13 & 0.01 \\
Serine & 0.80 & 0.85 & 0.79 & 0.85 & 0.85 & 0.02 \\
Threonine & $0.69^{\mathrm{a}}$ & $0.73^{\mathrm{a}}$ & $0.76^{\mathrm{a}}$ & $0.76^{\mathrm{a}}$ & $0.62^{\mathrm{b}}$ & 0.02 \\
Tyrosine & 0.16 & 0.15 & 0.16 & 0.15 & 0.16 & 0 \\
Valine & 0.30 & 0.29 & 0.31 & 0.29 & 0.28 & 0.01 \\
\hline
\end{tabular}

${ }^{\mathrm{ab}}$ Means within a row of either group (processing or fortification) with different superscripts are different at $\mathrm{P}<0.05$.

${ }^{1}$ Ethylene diamine tetra acetate; ${ }^{2}$ Standard error of mean.

\section{Conclusion}

Fortification of amaranth diets with casein improved broiler performance and availability of some essential amino acids. Lack of positive response from fortification with lysine or lysine plus methionine indicated that the two amino acids were not limiting in broilers fed on amaranth diets. Inclusion of EDTA did not enhance retention of minerals in the body. As demonstrated in this study, extrusion and fortification of grain amaranth diets with casein improved their utilisation by broiler chickens, while the utilisation of the minerals in unfortified amaranth diets was considered adequate. 
Table 8 Effect of processing and fortification of amaranth diets on mineral utilization at 31 days of age (Trial 2)

\begin{tabular}{lcccccc}
\hline & \multicolumn{2}{c}{ Processing } & \multicolumn{3}{c}{ Fortification } \\
& Raw & Extruded & None & EDTA $^{1}$ & Casein & s.e.m. \\
\hline Mineral retention (\%) & & & & & & \\
Calcium (Ca) & $48.2^{\mathrm{b}}$ & $54.6^{\mathrm{a}}$ & $51.8^{\mathrm{a}}$ & $51.7^{\mathrm{a}}$ & $50.7^{\mathrm{a}}$ & 1.00 \\
Phosphorus (P) & $48.0^{\mathrm{b}}$ & $51.2^{\mathrm{a}}$ & $47.2^{\mathrm{b}}$ & $51.3^{\mathrm{a}}$ & $50.3^{\mathrm{a}}$ & 0.75 \\
Magnesium (Mg) & $43.9^{\mathrm{b}}$ & $47.6^{\mathrm{a}}$ & $45.3^{\mathrm{a}}$ & $46.5^{\mathrm{a}}$ & $45.5^{\mathrm{a}}$ & 0.61 \\
Zinc (Zn) & $-0.39^{\mathrm{b}}$ & $-0.21^{\mathrm{a}}$ & $-0.36^{\mathrm{a}}$ & $-0.25^{\mathrm{a}}$ & $-0.28^{\mathrm{a}}$ & 0.04
\end{tabular}

Tissue mineral concentration (fresh basis)

Femur ash

$\begin{array}{lcccccc}\mathrm{Ca}(\mathrm{g} / \mathrm{kg}) & 366 & 377 & 363 & 374 & 378 & 3.1 \\ \mathrm{P}(\mathrm{g} / \mathrm{kg}) & 188^{\mathrm{a}} & 195^{\mathrm{a}} & 185^{\mathrm{a}} & 193^{\mathrm{a}} & 196^{\mathrm{a}} & 2.6 \\ \mathrm{Mg}(\mathrm{g} / \mathrm{kg}) & 13^{\mathrm{b}} & 16^{\mathrm{a}} & 14^{\mathrm{a}} & 15^{\mathrm{a}} & 14^{\mathrm{a}} & 0.6 \\ \mathrm{Zn}(\mathrm{mg} / \mathrm{kg}) & 461 & 466 & 467 & 463 & 461 & 1.47\end{array}$

Muscle (thigh)

$\mathrm{Mg}(\mathrm{mg} / \mathrm{kg})$

$194^{\mathrm{b}} \quad 198^{\mathrm{a}}$

$198^{\mathrm{a}}$

$192^{\mathrm{b}} \quad 201^{\mathrm{a}}$

$194^{\mathrm{b}}$

1.38

$\mathrm{Zn}(\mathrm{mg} / \mathrm{kg})$

$20.7^{\mathrm{b}}$

$22.0^{\mathrm{a}}$

$20.3^{\mathrm{b}} \quad 22.2^{\mathrm{a}}$

$21.5^{\mathrm{a}}$

0.33

Liver

$\begin{array}{lllllll}\mathrm{Mg}(\mathrm{mg} / \mathrm{kg}) & 376^{\mathrm{a}} & 378^{\mathrm{a}} & 373^{\mathrm{b}} & 381^{\mathrm{a}} & 378^{\mathrm{a}} & 1.14 \\ \mathrm{Zn}(\mathrm{mg} / \mathrm{kg}) & 35.5^{\mathrm{b}} & 39.2^{\mathrm{a}} & 37.8^{\mathrm{a}} & 37.8^{\mathrm{a}} & 36.5^{\mathrm{a}} & 0.62\end{array}$

Pancreas

$\begin{array}{lllllll}\mathrm{Mg}(\mathrm{mg} / \mathrm{kg}) & 450^{\mathrm{a}} & 453^{\mathrm{a}} & 442^{\mathrm{c}} & 460^{\mathrm{a}} & 452^{\mathrm{b}} & 2.26 \\ \mathrm{Zn}(\mathrm{mg} / \mathrm{kg}) & 42.0^{\mathrm{b}} & 46.7^{\mathrm{a}} & 41.5^{\mathrm{b}} & 45.5^{\mathrm{a}} & 46.0^{\mathrm{a}} & 0.95\end{array}$

Plasma

\begin{tabular}{lcccccc}
$\mathrm{Ca}(\mathrm{mg} \%)$ & $9.5^{\mathrm{b}}$ & $10.5^{\mathrm{a}}$ & $9.5^{\mathrm{b}}$ & $10.0^{\mathrm{ab}}$ & $10.5^{\mathrm{a}}$ & 0.21 \\
$\mathrm{P}(\mathrm{mg} \%)$ & $6.0^{\mathrm{b}}$ & $6.7^{\mathrm{a}}$ & $6.0^{\mathrm{b}}$ & $6.5^{\mathrm{a}}$ & $6.5^{\mathrm{a}}$ & 0.14 \\
$\mathrm{Mg}(\mathrm{mg} \%)$ & 3.0 & 3.2 & 3.3 & 3.0 & 3.0 & 0.08 \\
$\mathrm{Zn}(\mathrm{mg} / \mathrm{kg})$ & 2.8 & 3.0 & 3.0 & 3.0 & 2.8 & 0.08 \\
\hline
\end{tabular}

${ }^{\mathrm{ab}}$ Means within a row of either group (processing or fortification) with different superscripts differ at $\mathrm{P}<0.05$.

${ }^{1}$ Ethylene diamine tetra acetate; ${ }^{2}$ Standard error of mean.

\section{Acknowledgement}

The authors wish to thank the German Academic Exchange Programme (DAAD) for funding this study and the Institut fur Tierernahrung, Freie University, Berlin, Germany where work on amino acid analyses was carried out.

\section{References}

AOAC, 1984. Official methods of analysis (14th ed.). Association of Official Analytical Chemists, Inc., Washington, DC, USA. 
Becker, R., Wheeler, E.L., Lorenz, K., Stafford, A.E., Grosjean, O.K., Betschart, A.A. \& Saunders, R.M., 1981. A compositional study of grain amaranth. J. Food Sci. 46, 1175-1180.

Bressani, R., 1988. Amaranth: The nutritive value and potential uses of the grain and by-products. Food and Nutrition Bulletin, Vol. 10; No. 2. The United Nations University. pp. 49-59.

Bressani, R., Sanshez-Marroquin, A. \& Morales, E., 1992. Chemical composition of grain amaranth cultivars and effects of processing on their nutritional quality. Food Rev. Int. 8, 23-49.

Cheeke, P.R. \& Bronson, J., 1980. Feeding trials with amaranthus grain, forage and leaf protein concentrates. In: Proceedings of the second amaranth conference, Rodale Press, Emmaus, PA, U.S.A. pp. 5-11.

Erbersdobler, H., 1976. Amino acid availability. In: Protein metabolism and nutrition. Eds. Cole, D.J.A., Boorman, K.N., Buttery, P.J., Lewis, D., Neale, R.J. \& Swan, H., Butterworths, London. pp. 139-158.

Gupta, V.K. \& Thimba, D., 1992. Grain amaranth. A promising crop for marginal areas of Kenya. Food Rev. Int. 8, 51-69.

Hallmans, G. Nilson, U., Sjostrom, R., Wetter, L. \& King, K., 1985. The bioavailability of zinc in endosperm, whole grain and bran-enriched wheat crisp breads fed to rats on a zinc-deficient diet. In: Trace Elements in Man and Animal - 5. Eds. Mill, C.F., Bremner, I. \& Chesters, J.K., Commonwealth Agric. Bureaux (CAB), England. pp. 449-450.

Hewitt, D. \& Lewis, D., 1972a. The effect of dietary lysine level, restriction of food intake and sampling time on the levels of amino acids in the blood plasma of chicks. Br. Poultry Sci. 13, 387-398.

Hewitt, D. \& Lewis, D., 1972b. The amino acid requirements of the growing chick. 1. Determination of amino acid requirements. Br. Poultry Sci. 13, 449-463.

Kabuage, L.W., 1996. Nutritive evaluation of grain amaranth (Amaranthus spp.) in broiler chicken diets. $\mathrm{PhD}$ (Animal production) Thesis, University of Nairobi, Kenya.

Kauffman, C.S., 1992. Realising the potential of grain amaranth. Food Rev. Int. 8, 5-21.

Laovoravit, N., Kratzer, F.H. \& Becker, R., 1986. The nutritional value of amaranth for feeding chicken. Poultry Sc. 65, 1365-1370.

McNab, J.M., 1980. The concept of amino acid availability in farm animals. In: Recent advances in animal nutrition. Eds. Haresign, W. \& Lewis, D., Butterworths, U.K. pp. 1-9.

NRC, 1984. Nutrient requirements of poultry. National Academy of Sciences, Washington, D.C.

Oberleas, D., 1985. The effect of phytate on endogenous zinc and zinc homeostasis. In: Trace elements in man and animals - 5. Eds. Mills, C.F., Bremner, I. \& Chesters, J.K., Commonwealth Agricultural Bureaux (CAB), England. pp. 453-455.

Pedersen, B., Kalinowski, L.S. \& Eggum, B.O., 1987. The nutritive value of amaranth grain (A. caudatus). 1. Protein and minerals of raw and processed grain. Qualitas Plantarum. 36, 309-324.

Peisker, M. 1994. Influence of expansion on compounded feed components. Feed Mix. 2 (3), 26-31.

Pharmacia, 1988a. Handbook amino acid analysis, theory and laboratory techniques. Pharmacia LKB Biotechnology AB, Sweden.

Pharmacia, 1988b. Instruction manual, LKB amino acid analysis system. Pharmacia LKB Biotechnology $\mathrm{AB}$, Sweden.

Pond, W.G., Lehmann, J.W., Elmore, R., Husby, F., Calvert, C.C., Newman, C.W., Lewis, B. Harrold, R.L. \& Froseth, J., 1991. Feeding value of raw or heated grain amaranth germ plasm. Anim. Feed Sci. Technol. 33, 221-236.

SAS, 1988. Statistical Analysis Systems user's guide (6th ed.). SAS Institute Inc., Cary, North Carolina.

Scott, M.L., Nesheim, M.C. \& Young, R.J., 1982. Nutrition of the chicken. $3^{\text {rd }}$ ed. Scott, M.L. \& Associates, Ithaca, New York.

Sibbald, I.R., 1986. The TME system of feed evaluation: methodology, feed composition data and bibliography. Technical Bulletin 1986-4E. Research Branch, Agriculture, Canada.

Teutonico, R.A. \& Knorr, D., 1985. Amaranth: Composition, properties and applications of a rediscovered food crop. Food Tech. 39, 49-61.

Tillman, P.B. \& Waldroup, P.W., 1986. Processing grain amaranth for use in broiler diets. Poultry Sci. 65, 1960-1964.

Wallis, I.R. \& Balnave, D., 1984. A comparison of amino acid digestibility bioassays for broilers. Br. Poultry Sci. 25, 389-399.

Watkins, K.L. \& Southern, L.L., 1993. Effect of dietary sodium zeolite A on zinc utilisation by chick. Poultry Sci. 72, 296-305. 